\title{
NGOLO: (Re)membering the African American Child as a Normative for Self-Healing Power
}

\section{Patricia Nunley \\ ORCID iD: https://orcid.org/0000-0003-3437-8135}

\section{Abstract}

In response to the need to clarify the ongoing experience of historical and contemporary trauma by African American people in the USA, Dr. Wade Nobles, co-founder and past President of the ABPsi introduced the concept of 'Psychic Terrorism' which he defined as the systematic use of terror to immobilize and/or destabilize a person's fundamental sense of security and safety by assaulting his or her consciousness and identity (2015: 4). The USA's practice of psychic terrorism demands that special attention be given to African American children's identity development. In this regard, the unconstrained, western research's dominance continues to function as a hindrance to the understanding of Black children's positive identity development and resultant well-being. In this context the African child's double invisibility (Jonsson 2009; Nsamenang 2007), obscurity and under-publication, and the African American child's double visibility, pathologies and over-publication (Jackson \& Moore 2008; Kunjufu1992), inhibits an appreciation of Black children's substantive self-identity knowledge. The consequence of this for the African Child is unrecognition of their normativity as the universal original child. For the African American child, this unrecognition also impairs their connection to their generative African essence or Ngolo. Ngolo, as defined by Fu-Kiau, means in Kikongo, the 'energy of self-healing power'. By employing the child development discipline, this article will problematize the minimization of the African child as the norm while illuminating the critical need for African American children to function in wholeness and wellness. The idea of wellness being evidenced in the sense of being fundamentally Spirit (often confused with spiritual ${ }^{1}$ ) is most often missing in western conceptions of human

Nobles (see Nobles and Mkhize, this edition) has noted that the misunderstanding of African beingness, i.e., as 'human being' and not 'Spirit 
develop-mental domains, i.e. spiritual. In the domain of wellness, belongingness to the past and future exists and enables Black children to function within three realms, i.e. the being, been, and will be (Fu-Kiau 1969: 1991) wellness is elicited via access to their Ngolo. This author seeks to articulate the need for African American children to '(re)member' (Nobles 2017) and connect to their self-healing power.

Keywords: African-American child, Ngolo, Self-identity knowledge, Spirit, wholeness, belongingness, wellness; self-healing

\section{NGOLO: Ukukhunjulwa Kwengane yase Melika Engum-Afrika Njengesu Lokuzelapha}

\section{Patricia Nunley ORCID iD: https://orcid.org/0000-0003-3437-8135}

\section{Iqoqa}

Ukubhekana nesidingo sokucacisa ngolwazi olusemlandweni kanye nolwamanje lokuhlukumezeka kwabama-Afrika abangamaMelikana ezweni laseMelika, uDkt. Wade Nobles, ongomunye wabasunguli noMongameli owedlule wenhlangano i-ABPsi, wethula ikhonsepthi ebizwa nge-'Psychic Terrorism'(ukwesabisa engqondweni), ayichaza njengetulo lokwesabisa ngenhloso yokwenza ukuthi umuntu ahlalele ovalweni, ukuze aphelelwe ukuzazi nokuzigqaja ngobuqobo bakhe (2015: 4). Udlame lwaseMelika lokwesabisa engqondweni ludinga kulandelwe ukuthuthuka kobuqobo kwabantwana baseMelika abangama-Afrika. Ngale ndlela, ukubusa kocwaningo lwasentshonalanga olungavinjelwe kuzoqhubeka nokuba yizihibe ekuqondeni ukuthuthuka kobuqobo kwezingane ezinsundu nemiphumela

Being' has resulted in the misidentification of African 'spiritness' as simply spirituality. In accord with this correction, this discussion will correctly use Spirit and not spirituality 


\section{Patricia Nunley}

emihle yalokhu. Kulesi simo, ukungabonakali kwezingane zase-Afrika (Jonsson 2009; Nsamenang 2007), ukungaveli kanye nokugqoza kwemibhalo ngazo, kanye nokuvezwa ngokuphindiwe emibhalweni eminingi ngezingane zabansundu baseMelika (Jackson \& Moore 2008; Kun-jufu1992), kuvimbela ukwazisa ngolwazi olwanele lokuzazi ubuqobo lwezingane ezinsundu. Imiphumela yalokhu enganeni engumAfrika ukunganakwa kwabo nokungabi bikho kwemigomo ngabo njengezingane zendabuko jikelele. Enganeni yaseMelika engumAfrika lokhu kushawa indiva kuba nemiphumelo emibi ngoba kwenza zingabi nobudlelwano nemvelaphi yazo noma lokhu okubizwa ngeNgolo. INgolo ngokukaFu-Kiau, ngesiKikongo, ichaza amandla okuzilulamela. Ngokusebenzisa isifundo sokuthuthuka kwengane, leli phepha lizoveza inkinga yokuncishishwa kwengane yase-Afrika njengesihlava esamukelekile kube kodwa kunokuqhakambiswa kwezidingo ezinqala zezingane zase-Melika ezingama-Afrika zokuphelela nempilonhle. Umbono wempilonhle obonakala njengesisekelo soMoya (okubuye kuphambaniswe nokuba nomoya) uhlezi ungekho ezincazelweni zasentshonalanga ezikhuluma ngokuthuthuka komuntu. Esizindeni sempilonhle, ukuba yingxenye yomlando othile kanjalo nekusasa kukhona futhi lokhu kwenza izingane ezinsundu zikwazi ukuba yingxenye yemibuso emithathu yempilonhle, okuyile, yilokho oyikho, yilokho obuyikho, kanye nalokho ozoba yikho (Fu-Kiau 1969: 1991) okutholakala kuyona iNgolo yabo. Umbhali uhlose ukucacisa isidingo sezingane zaseMelika ezingama-Afrika 'ukukhumbula (isibili)' (Nobles 2017) ziphinde zixhumane namandla okuzilulamela.

Amagama asemqoka: ingane yaseMelika engumAfrika, iNgolo, ulwazi ngobuqobo, uMoya, ukupheleliseka, ukuba mdibi munye, impilonhle, ukuzilulamela

\section{Introduction}

Being Black in the USA is a risk factor. This statement is a reflection of the experience of many African Americans who, as citizens in their country, have been subjected to a host of racially driven experiences that have caused them to question not just their physical safety, but their societal worth. While this African American perception of life in the USA is not new, it is especially concerning within the context of this nation's identification of violence as a 
public health concern (Wen \& Goodwin 2016). For young African American children, race, combined with their developmental life stage, creates a greater need for protective resources. Becoming aware of their African identity is an innate powerful asset that is available to all African people, and is especially important for children in the process of identity formation. In a detailed discussion of mental ideations, i.e. memes, Dr. Nobles suggested that we should (re)member, defined as reclaiming or recalling, the mental ideations that are grounded in our African heritage (Nobles 2017). (Re)membering is reclaiming or recalling our innate Africaness. The goal of this article is to articulate the critical need for African American children to (re)member their African identity and experience the benefits inherent when one fully functions as a Spirit Being. These benefits include self-healing power and an extended self that translates to an African child always feeling the protection of their community.

The article begins with an articulation of an African view of human development. A discussion about African Americans' subjection to racially driven violence including the 'denial of the validity of African people's humanity' (Nobles 2001: 8) is accompanied by a collective and ever-present total disregard and disrespect for the African and the right of people of African ancestry to exist, i.e. the maafa. ${ }^{2}$ This is followed by a discussion regarding the need for the African American children to learn about their African identity as a critical protective factor, and the call for all early childhood professionals and caregivers of African and African American young children to take responsibility for teaching these children African-self-knowledge.

${ }^{2}$ Introduced by Marimba Ani, maafa is a great disaster and misfortune of death and destruction beyond human convention and comprehension. The African maafa is not a single abhorrent event in history. It is an on-going, sophisticated, continuous 'process' supporting worldwide white supremacy; driven by fear and racial hatred and designed to dehumanise and/or destroy African people. The critical feature of the maafa is the denial of the validity of African people's humanity, accompanied by a collective and ever-present total disregard and disrespect for the African and the right of people of African ancestry to exist. The African maafa gives licence to the continual perpetuation of a total systematic and organised process of spiritual and physical destruction of African people, both individually and collectively. 


\section{African Human Development}

Globally, early education programmes have adopted the western version for young children's positive growth and development. Often, this knowledge was generated by researchers studying their own offspring (Darwin 1877; Piaget 1963; Skinner 1944). In their collective arrogance, western scholars compiled knowledge and conceived theories without the inclusion of the African child. As the original child, the African child offers a window into the notion of universal child development and yet studies on these children are sparse, and when they occur, they are under published. Nsamenang (2007) identifies this phenomenon as rendering the African child 'double invisible'. Conversely, the African Americans in the USA are disproportionately the subject of deficit research and found to be in need of intervention (Toldson 2019). These studies are typically overpublished and position the African American child as 'double visible' (Jackson \& Moore 2008; Kunjufu 1992), and the model for negative growth and development. In his recent work, NO BS (Bad Stats) 2019, Toldson articulates the utilization of statistics by educators and advocates to denigrate and dispirit Black students; the outcome is internalized negative emotions that lead to self-isolation from their peers, community, and culture. Forcing students to adapt to racially biased curriculum to succeed is especially concerning when the epistemological underpinning is antithetical to African ancestry people groups. As an early childhood educator who recognises the value of providing young children with opportunities that allow for optimised growth and development, the striking contrast between the African child's 'invisibility' and the African American child's 'double visibility' is particularly concerning.

Logically, the African child's membership in the original human group positions him or her as the candidate for exploring the notion of a universal pathway for child development. Instead, the field of early childhood development has relied upon Western scholars' study of 5\% of the world's children to comprehend the other $95 \%$ of children (Zukow 1989). This academic arrogance predictably can hinder the development of Black children, both in the African motherland and in the African Diaspora. This is especially true when these young children are growing and developing in environments where they are subjected to multiple risk factors the most recent being the twin pandemics of the novel COVID-19 and the overt displays of classist racism. For Black children, an innate source of protection exists in their 
African identity as Spirit Beings, the understanding of which should be grounded in African-centred ideas and concepts. One such concept is ngolo. The idea of ngolo is a generative healing source that allows one to not just survive, but to thrive.

\section{Problematisation of Western Thinking}

The application of western thinking in the understanding of the development of African children is problematic in that it fails to illuminate the critical need for Black children to know their African self and the power that exists within them as African people. Western theory states that the acquisition of a selfidentity begins in early childhood, and is later completed during the adolescent life stage (Erikson 1982). In the African view, the child enters the physical world with an identity. The child, like all Africans, has what can be described as possessing three distinct identities, namely: a been-self, a being self, and a yet-to-be self, all of which are both spirit-defined and spirit-driven (Fu-Kiau 1969). The co-existents of identities is articulated by Nobles (1976) as an extended-self, and can be understood using the ontological principle of consubstantiation (Akbar \& Nobles 2006). Within this context, the being-self functions in the physical or visible world. Significantly, the African conceptualisation of human development includes a Spirit domain that connects all Africans to a single source that represents the original life force. Western thinking, however, views human development as occurring through three interdependent domains identified as biological, psychosocial, and cognitive. There is no Spirit domain or metaphysical connectivity between individuals or a life force. In this view, the physical world is made of more mature individuals who, during the childhood life stage, are tasked with 'acquiring' a self-identity.

From an African worldview, the only 'self' is an 'extended-self or collective-self' that is connected to one single life source (Fu-Kiau 1969). The co-existing identities are articulated by Nobles (1976) as an extended-self, and can be understood using the ontological principle of consubstantiation (Akbar $\&$ Nobles 2006). Within this context, the being-self functions in the physical or visible world. Significantly, the African conceptualisation of human development includes a Spirit domain that connects all Africans to a single source that represents the original life force. Western thinking, however, views human development as occurring through three interdependent domains 


\section{Patricia Nunley}

identified as biological, psychosocial, and cognitive. There is no Spirit domain or metaphysical connectivity between individuals or a life force. In this view, the physical world is made of more mature individuals who, during the childhood life stage, are tasked with 'acquiring' a self-identity (Erikson 1982).

From an African worldview, the only 'self' is an 'extended-self or collective-self' that is connected to one single life source (Fu-Kiau 1969). Life cannot exist without this connection. Significantly, this connection is operationally expressed as $u b u n t u^{3}$ or the connectivity that allows all to be. Ubuntu is the cosmic universal force and is often simply defined or translated as 'I am because we are'. Accordingly, for the African, identity not only exists in three different forms, the past, the present, and the future, but also in two different realms i.e., the seen or physical world, and the unseen or metaphysical world. What western theory defines as resiliency for the Black child, is, a manifestation of their African extended or collective self. As noted above, no African or Black person, including their children, is ever a separate self. Based on an African identity, separateness and individualism is not a possible state of existence. The Black child is never alone. Always being in the company of others (visible and invisible) offers a particular comfort to a young child who, based on their developmental stage, depends more upon mature others for both survival and comfort. The consubtantive nature of their identities, existing within the visible and invisible world represents an added bonus based on the ability of ancestors to become the "Living" when deemed necessary (Nsamenang 2006).

\section{The African American Child}

The three states of being, i.e. been (ancestors), being (living), and will-be (unborn), that exists in all African people (Fu-Kiau 1969), is also present in African Americans and all African diasporic people. This Africanness or Africanity allowed for the collective survival from the maafa (Ani 1997; Latif \& Latif 1994) experienced by today's children of African ancestry. The level of brutality enacted upon the number of Africans who were enslaved and

${ }^{3}$ Ubuntu is a core African philosophy (Kikongo) that asserts that the process of becoming $n t u$ or 'Spirit' in which being and beings coalesce, wherein Spirit also manifests one's interactions with the totality of creation. 
survived this traumatic violence cannot be explained as simply resilience. Leary (2005), in her seminal work on the impact of the transatlantic slave trade, referred to as maafa (Latif \& Latif 1994), provides a comprehensive view of the historical trauma experienced by this African diasporic people today. She conceptualizes this historical trauma as post traumatic slave syndrome or PTSS (Leary 2005). While her word choice of 'post' may confuse the reader into comprehending the negative impact of this racially-informed trauma violence as a past event, this is not Leary's intent. The systemic inhumane treatment of African Americans did not end with the ban on chattel slavery. In reality, the systemic inhumane treatment of African Americans did not end with the ban on chattel slavery.

The systemic inhumane treatment of African Americans did not end with the ban on chattel slavery. These anti-Black iterations include racial segregation known as Jim Crow Laws, the establishment of a white Nationalist terrorist group named the Klu Klux Klan or KKK, peonage via sharecropping, and barbarism disguised as science (Kapsalis 1997; Washington 2008). Michelle Alexander's seminal work entitled The New Jim Crow (2010) illuminates the ways in which the disproportionate incarceration of Black males represents an intentional practice for a free/extremely low cost of human labor source. Nobles (2015) offers the term 'psychic terrorism' to describe the continued iterations of violence against the Black citizenry of the Unites States. His articulation illustrates the constant and persistent assault experienced for individuals living in a psychologically toxic and violent society. Notably in the context of the 2020 novel COVID-19 pandemic, African Americans are being subjected to a new form of psychic terrorism in the form of the twin pandemics of a deadly infectious disease combined with overt deadly acts of anti-Black racism (Laurencin \& Walker 2020).

As previously noted, the three states of being, i.e. Been (ancestors), being (living), and will-be (unborn), that exists in all African people (Fu-Kiau 1969), is also present in African Americans and all African diasporic people. This Africanness allowed for the collective survival of the maafa experienced by today's African American direct African descendants. Literature on the level of brutality enacted upon the number of Africans who were enslaved and survived this traumatic violence cannot be explained as simply resilience.

The ability of African Americans to survive, and for some thrive, in the face of this psychic terror has been examined through a western lens that is consistent with the Western preference for individualism and obsession to 


\section{Patricia Nunley}

quantify and measure people and events. The National Scientific Council on the Developing Child at Harvard University (2015) has established a set of characteristics that enable an individual to be resilient. They are as follows: a) at least one stable, committed relationship with a supportive parent, caregiver, or other adult; b) a biological resistance to adversity and strong relationships with the important adults in their family and community; c) a sense of selfefficacy and perceived control; d) opportunities to strengthen adaptive skills and self-regulatory capacities; and e) access to the mobilising sources of faith, hope, and cultural traditions. Significantly, this western articulation believes that learning to cope with manageable threats aids in the development of resilience; acquisition of resilience can occur at any time. This cognitively bonded analysis continues to ignore the foundational Spirit essence of African Americans who retain their Africanity regardless of their diaspora location. This western premise unfairly views African American children, whose ancestors endured chattel slavery and related subjection to complex trauma, as disproportionately inheriting the collective ability to cope with stress and trauma based solely on their ethnic/racial group membership.

A related body of work is presented to illustrate USA scholarship that focused exclusively on resilience in African American children and youth (APA Task Force on Resilience and Strength in Black Children and Adolescents (2008), these scholars recognized the uniqueness of the Black experience I the USA and applied a strength based, as opposed to deficit or pathological supporting approach, In their conceptualization, Spencer (2005) PVEST model was used to capture the sociohistorical and political realities of African Americans; from this framework five domains of development accompanied with behavior descriptions were established as exemplars for wellbeing. The domains and related examples are as follows: (a) identity (communal or extended-self identity; (b) cognitive (academic self-motivated toward excellence strong inter and intra personal intelligence); (c) social (genuine respect and concern for the well-being of family, school, and community; (d) emotional (emotional intelligence that includes self-regulation of destructive emotions) and; (e) physical health (rejection of dietary and activity patterns that increase negative health outcomes). From this comprehension they identified four dimensions that contribute to the aforementioned optimal functioning that translates to the following four protective factors: they are (1) critical mindedness; (2) active engagement; (3) flexibility, and (4) communialism. Conceivably, African American scholars 
contributed to this work. Unfortunately, based on their conceptualization, what Kambon (2012) identified as pseudo-Afrocentricity is present. While focus on the African American culture guided their conceptualization, the uncritical adoption of Eurasian thought results in the arrested thinking that is inherent in the Eurocentric knowledge base that erroneously touts universal applicability, In their articulation, they identified the communal or extendedself-identy as a protective factor but did so using the Western view that ignores/omits/denies the metaphysical realm as a factor in optimal functioning. By limiting their articulation to the physical realm and horizontal connectivity with animate beings they missed the wholeness and the ontological consubstantiation nature of their African identity (Fu Kia, 1969; Nsamanang, 2006). The omission of African Beingness translates to not only denial of a key protective factor that aids in wellbeing, but also will at a minimum limit the efficacy of mental health strategies that target African Americans. Given the developmental vulnerability of young children, application of models that fail to recognize Black children as Spirit Beings can also retard or even harm the development of their foundational Spirit domain.

In summary, Western-informed models are not suited for comprehending African American development; this view does not allow for the development of strategies for optimized functioning and the identification of protective characteristics that result in resiliency, This is evidenced by the fact that the application of the resilience factors from the Harvard findings would not have been sufficient to survive the maafa experience (Latif \& Latif, 1994). For the Africans who were initially enslaved, the identified components for resilience did not exist. For example, physical relationships were violently severed, self-efficacy and perceived control was denied, and access to resources that allow for cultural grounding and the resultant hope was no longer possible. Consequently, Africans' survival of the maafa cannot be explained as simply resilience, a greater force was in effect; this same force continues to operate as a source that allows for not just basic collective African American survival, but in come instances results in extraordinary thriving in the context of unrelenting complex trauma. In the current context of the USA the need for African resilience is especially important to maintain the level of wellness needed to be resist the impact of what Nobles (2020) recently identified as White Supremacy Mental Illness 19 (WSMI-19) that began in 1619; he informs us that not all Whites are infected by this disease but those that are exhibit anti-Blackness that may have epigenetic roots. 
In the context of the current manifestations of WSMI-19, more young African American children have been subjected to racist attacks that disregard their humanity and that of their families. Two examples are the police shooting of Jacob Black in the presence of his three young children ages 3, 5, and 8 on August 26, 2020; the second traumatic police encounter occurred 24 days earlier when a Black mother and her 4 daughters ages 6-17 on August 2, 2020. In the latter incident the police mistakenly believed the mother was driving a stolen vehicle and during the traffic stop ordered the entire family to lie face-down on the ground; the order was given while guns were being pointed at the family and at least two family members were handcuffed (Bonvillian, 2020). While information on these encounters are still ongoing, two prior events that demonstrate African American children's subjection to physic terrorism is provided below to support the need for Black children to comprehend their Africanness and embrace it as a protective factor.

The first is an incident that occurred on July 6, 2016. While strapped in a car seat in the rear of a vehicle, a four-year-old girl witnessed her mother's boyfriend, Philander Castile, being killed by a police officer. During a traffic stop, the police officer placed his gun inside the vehicle and shot multiple bullets into Mr. Castile's seated body. Immediately following this deadly incident, the child and her mother, Diamond Reynolds, were locked in the rear of a police vehicle. The Dashcam video recorded the interactions between the handcuffed mother and her daughter. As Ms. Reynolds cried out in agony and despair, the child was observed comforting her mother. The child tells the mother, 'I can keep you safe' and to be calm because 'I don't want you to get shooted' (Schladebeck 2017). This recorded exchange is emotionally charged and extremely disturbing in terms of the child's development when comprehended from a western lens.

On August 1 of the same year, a second US example of the violent psychic terrorism experienced by young African American children occurred in the shooting incident of a mother, 23-years-old Koryn Grains, along with her five-year-old son, in their apartment. While present to serve a warrant, police shot the mother and son after a seven-hour stand-off. The mother died and the son was shot in his left cheek. He states he was shot while he was running away from the police. Authorities state the bullet that shot him first went through his mother. Five months' prior the mother was stopped by the police while driving with her five-year-old and her one-year-old daughter. During the stop the mother video-recorded the encounter, which included a 
verbal discussion with her son about police killing of Black people; with Ms. Gaines telling him to 'fight them asses if they tell you to get out of the car'. She also states her sons will be rebels and live on forever. During the deadly encounter at the apartment, the mother live streamed the event on Facebook, critically prior to the shooting the police were able to shut down the streaming. In this incident, the police bodycams were not operating. There is documentation that Ms. Gaines suffered from mental illness as a result of lead exposure (Green 2016). An excerpt of her video-recorded words below prior to being arrested during the traffic stop revealed a disturbing reality for African Americans in the USA:

... I can pull a video up right for him right now of you killing people for no $\mathrm{f}[\ldots]$ king reason. People who look like his father, his uncle, his sister, his brother, his anybody ... (Korryn Gaines 2016).

In both cases the police officers were not charged for the deadly shootings. Two years later, a jury awarded civil damages to the Gaines family to the amount of $\$ 37$ million. However, a year later, in February 2019, a judge overturned the decision and the family is planning to appeal. The Black Lives Matter movement was conceived as a result of the continuous subjection to what has been defined as 'State sanctioned violence' and police officers not being held accountable. Significantly, young children have been directly involved in protests that include raising their hands in surrender and entreating, 'don't shoot!', or laying on the ground and pleading, 'I can't breathe!' Both of the young African American children directly involved in these police killings of their caregivers/ protectors survived, and are reportedly alright, given the circumstances.

To date, police continue to disproportionately exhibit the need to collectively control the movements of Black bodies and the murder rates of unarmed Black people continue to rise (Mapping Police Violence 2017). Critically, during and following the national COVID-19 informed shelteringin-mandates, non-police Whites have taken it upon themselves to also police the movement of Black people (Romo, 2020). As a mother, an early education professor, and simply a human being, these incidents are especially impactful. When applying western knowledge to these events, one is left feeling much like the mother of the four-year-old handcuffed in the rear of the police vehicle. Agony, despair, and hopelessness are accurate descriptors that predictably 


\section{Patricia Nunley}

transcend to frustration, anger, and even rage. Fortunately, as one who actively seeks to connect with their African identity for the purpose of maintaining wellness and wholeness, personal communication with African-centred psychologists consistently provides both healing and spiritual comprehension. In a discussion about this event, African-centred psychologist Baba Wade Nobles was quick to point out the fact that the Ancestors stepped up to speak to the mother through the child, so as to restore order in the midst of this traumatic chaos (Personal Communication 2016). Indeed, the recording reveals the child's words that 'it [was] going to be okay'. were effective, and allowed the mother to re-gain her composure and to once again fulfil her role as the child's protector. This in turn comforted the child, and the two were able to continue functioning in their state of being-self. Once this was accomplished, the been-self in the child and mother was able to return to their metaphysical world with the knowledge that life would go on and the way would be made for the will-be to enter into this world at a future date (Mbiti 1970). Put simply, the child's extended-self came forth to speak to the mother.

In the second incident, the five-year-old-boy's mother is talking to him not as a child, but as an adult who is expected to function in a manner that recognises what it means to grow and development in the context of psychic terrorism. In this case, western theory would view the mother as inappropriately subjecting the child to traumatising events, or as psychologically delusional . She is not preparing her child for play, instead she is preparing him for war. She is telling him to become a warrior and to fight for his life and for the life of others who look like him. Unbeknownst to us, five months later, this same child would be in a situation where his life and that of his mother's would be threatened by police officers. From a western view, the mother's earlier recorded conversation was evidence of the mother's mental illness, where an order for removal from his mother could have occurred. Yet from an African view, it is conceivable the Ancestors spoke through the mother to prepare the child for the deadly encounter (Mbiti 1970) that resulted in his mother being killed, and him being shot. Notably, during the standoff the boy elected to remain with his mother, and was given permission by his younger sister's father to join his mother after he was invited by the police to leave the apartment. This African American child survived the encounter. Was it resiliency, or his African Ancestors preparing him? This author believes the latter.

In the first incident where the four-year-old girl was strapped in the car-seat, the been-self (past/Ancestors) arose in the being-self (present) of the 
child in response to the mother being handcuffed in the rear of the police car. In the second incident with the five-year-old, the will-be self (future) arose in the mother while talking to her five-year-old son who, five months later, would not only be shot, but would also witness his mother dying from the gun shots. In both situations, the African American children were able to survive the traumatic violence in the moment and have been able to go forward. The existence of a been-self and will-be-self provides an explanation for these children's survival of this experience. Absent their Africanness and the involvement of their ancestors, neither of these children would have come to be, i.e. survived the maafa.

Through a western lens, we comprehend a child taking on what we perceive as an adult role, i.e. protector, as negative. We negatively view this behaviour as 'parentification', and admonish adults for their failure to function in the role of protector. Western thinking arrogantly informs the world that the work of the child is play, while failing to take responsibility for their role in treating the world as their own adult 'playground' via colonisation, imperialism and actions to control the world's natural resources and monopolise natural spaces for vacationing and holidays. Their actions create a world of war zones, in which too many children are now forced to grow and develop. From an African stance the behaviour of Black children who are White defined as 'parentified' may reflect the Black child's been-self or Ancestors acting through the child, just as they did in the case of the four-yearold young child to calm her handcuffed mother while they were in the rear of the locked police car. Through functioning as a been-self, or ancestor, the child as a being-self is positioned to ensure the survival that is necessary to bring forth the will-be-self. While this may be difficult based on the traumatic nature of the event, survival becomes possible and the explanation for this outcome cannot be comprehended as simply resilience.

\section{The African Child}

AIDS had a disproportionately fatal toll on Africans and left an unprecedented number of children as the primary caregivers for their younger siblings (Bey 2004; Wild 2001). In the past, other adult relatives would take on the responsibility of raising these children. Unfortunately, the toll enacted by this specific disease has resulted in not having enough adult relatives for the numbers of children with deceased parents. The outcome is a generation of what 


\section{Patricia Nunley}

western theory would categorise as 'parentified children'. This negative conceptualisation is made worse by the social stigma attached to this infectious disease.

To address the disease, imagine a healing approach that celebrates these children as the living examples of their ancestors functioning in the physical world with everyone. Imagine these being-self children as the beenself Ancestors who have left the invisible realm to commune with those in the visible or being world. Bestowing this type of reverence upon these being-self children who are raising their siblings would conceivably function as a healing medicine to fight the disease of social stigma and the resultant isolation. Consider the importance of re-positioning these youths as sacred members of the community and as the ancestors' chosen ones, as opposed to those whose parents AIDS has stolen. The western comprehension of human development will not allow for this view. Its limitation to a single physical view of being does not allow for an acceptable escape to a metaphysical state. Instead, it would identify escapism as a form of a mental disorder defined as 'disassociation', and from this medical model, one would engage in therapy to assist the individual in accepting their current being, and to learn to cope accordingly. The African child in this situation must be reminded of their African identity as possessing three states that are both physical and metaphysical. Through accessing their been-self, they can function as wise adults, who have experienced both joy and pain, and who know that this too shall pass. At the same time, other Africans who are in the environment with our children must remember their own African connectivity, and find ways to include other Africans, and especially young children. They must employ the concept of ubuntu and not fall prey to the western behavior of individualism.

In terms of the African child whom child development scholars have rendered as 'double invisible' (Jackson \& Moore 2008; Kunjufu 1992), the child soldier is perhaps the most challenging group in Africa. The fact that these children have been forced to participate in brutal murders of their family members and to commit atrocities against adults (Kaplan 2005) is a form of maafa in the Motherland. While this author has no direct experience about this deviant human behaviour, and, therefore, is beyond the scope of this current article, it is conceivable that traditional healing practices can be applied using the basic comprehension of African connectivity through the three stages of being. It may be that a cure is impossible if the focus is solely on the beingself, where forgiveness cannot be achieved (Twun-Danso 2003) for either the 
child soldier who cannot forgive his/herself, or the victim who has directly or indirectly been impacted by the acts of the child solider (Solheim 2003). Hope is found in the knowledge of the African identity that includes the foundational Spirit domain, where the ngolo resides and can generate healing power. This metaphysical place of hope is also where the connectivity to a space before and after the current disconnecting behaviours occurred. Perhaps the connectivity can then restore wellness and wholeness to both the child soldier and those harmed by their actions.

\section{African Identity: The Protective Source for the African American Child}

In returning to the African American child who lives in the context of a nation who has identified violence as a public health concern and whose cultural affinity membership makes them a target for multiple systemic, cultural, and individual risk factors, a conscious awareness of their African identity is a powerful protective factor. In the US literature they are overrepresented in studies designed to portray them as inferior. This identification then positions them as the continuous subjects of intervention techniques (Toldson 2019). A current example is found in the trauma-informed movement. The plethora of publications written under this banner on African American children has resulted in their becoming the 'poster child' for intervention services. The pathologising of these children, combined with their subjection to psychic terrorism, is evidence for the need for their caregivers and teachers to assist these children in (re)membering (Nobles 2017 personal communication) or awakening their African-Self. To do so, and specifically during their early life stages, where identity development is a foundational developmental task, would afford these children an invaluable gift for survival and self-healing.

For the African child, accessing their ngolo is an easier task. It is based simply on being surrounded by other Africans, who have not lost, or are rescuing their African identity. So, they also do not lose their resultant ways of Being and functioning in the three physical and metaphysical states. Residing in the Motherland, despite the western footprints and current handprints throughout the early childhood education programmes allows for ready reference to self-knowledge, e.g. customs and practices, language, names, land, space, etc. For the African American child whose experiences in the US have been designed to extinguish their African self (Akbar 1984), it becomes 


\section{Patricia Nunley}

necessary to engage in the process of (re)membering (Nobles 2017 personal communication) that provides for the reclamation, recollection, and rescuing of the mental ideations that are grounded in our African heritage through an extended-self that allows for connectivity in both the physical and metaphysical realms.

The western comprehension of human development and its blatant disregard for non-western and especially African thought (Masowa, Gopo \& Mamvura 2013) creates a challenge for the African American child to fully develop. In the Western view, humans develop in three interconnected domains that include the biological, psychosocial, and cognitive. All things, including violence are experienced through these domains and therefore must be addressed via one or more of these domains. Western thought uses a medical model for disease and illnesses. This separation results in treatment approaches that cause a person to go to a medical doctor for stomach pains and a psychiatrist or psychologist for emotional/mental discomfort. In this context, the trauma or psychic terrorism as articulated by Nobles (2014) would be treated via a focus on the psychosocial domain. There is no regard for the individual's Spirit, and as such, the treatment focus is on 'curing' as opposed to 'healing'. The western view also comprehends the early childhood life stage as that period where a sense of self or identity is acquired. While older others assist young children in this acquisition, the outcome is a self-identity. Their group identity is initially determined by society based on the individual's race or other phenotypical characteristics. For the African American child, this is an unacceptable identity development pathway.

The African comprehension of human development includes a spirit domain that is foundational, and which allows for connection to all things in both the physical and metaphysical world. The individual exists as an extended-self whose developmental task is to determine their purpose as member of the group. Their group identity is pre-determined as they enter the physical world already connected to the ancestors who reside in the metaphysical realm, and is already connected to the others who are functioning in the physical world. For the young child, the developmental task is not to find out who they are, but to determine ways in which their being can contribute to the others to whom they belong. It is not a matter of learning the best way to earn societal acceptance. Acceptance is a given, and the task is learning to show appreciation for the unearned acceptance (Nsamenang 2006).

Unlike the African child, the African American child in the US is cate- 
gorised as a minority within a larger group of non-white people. Along with this categorisation is the societal belief that Black people are the least valuable or respected of non-white people (Cross 1995), with the corollary that anything African would represent inferiority (Akbar 1984; Masowa et al. 2013). This societal belief has recently been reinforced with the outgoing forty-fifth US president infamously describing the place of their ancestors as 'shithole countries' (Brown 2018). While the opportunity for these children to manifest their African-self exists within the child's smaller African American community (McAdoo 2006), in the larger societal context the young African child is expected to acquire the western self-identity, and to do so in the face of the non-acceptance of their African identity. Historically for African American families, religion and church attendance served as a mechanism for survival that has fortified Black people against racism and from a hostile White world (Hill 2003; Staples 1997). This space provided an arena for support and the release of pent up emotions (Abney \& Priest, 1995) and makes the case for the need for young African American to nurture their Spirit development. Critically while early education programs tout their acceptance and celebration of all their student's cultures, the reality is few non-religious, public programs incorporate the non-Eurocentric conceptualization of human development that recognizes the Spirit as a developmental domain. Educational research also reveals the general existence of a poorness and/ or conflictual relational fit between an African American child and their non-Black teachers (Iruka et al. 2020); this is especially concerning given the fact that these young students are growing and developing in a racist society that actively seeks to deny their humanity. This is especially concerning given their young developmental life stages and translates to a unique need for international nurturing (Williams 2013). This litany of factors creates a synergistic need for protective resources that not only allow the African American child to experience a sense of Belonging, but also to develop the skills to confront and survive anti-Blackness racism while learning that the racist individual, and not their Black identity, is the problem.

\section{The Call for Living Adult Spirit Beings}

As the oldest human people and the adult Spirit Beings present in the physical world, all African scholars, educational professionals, and caregivers are charged with guiding their groups' children into their Spirit fullness. The 


\section{Patricia Nunley}

failure to do so not only leaves these young children who are becoming Spirit Beings with less protection, but also unnecessarily causes them to expend energy toward surviving. Conceivably, when this occurs, the Ancestors unknowingly will leave the invisible realm and return to the physical realm. The role of both African and African American adults is to function in the physical realm in a manner that adequately prepares for the entry of the yet-tobe.

Amos N. Wilson (1991), an African American scholar reminds us that African children are naturally precious and gifted and therefore African American children as their diaspora counterparts have the advantage of what he defines as 'Afrikan natural genius'. The African nature of African Americans is evidenced in their ways of being and can be observed through the lens of specific developmental domains. It can be found in their African Vernacular or Ebonics (V. Nobles 2015), their rhythmic physical movement (Akbar 2003), and their collective approach to cognitive problem-solving (Hale-Benson 1986; Hilliard 1995). In addition to their exhibitions of shared African heritage, literature reveals African Americans have a long history of engaging in behaviours that indicate a spiritual belief system that is evident in phrases like 'the Lord will provide' (Hill 2003; Staples 1997). An observation of their uniform response to the news of another State-sanctioned murder, the killing of a Black person by a police officer, and emotional expressions of extreme states of joy or pain, reveals the people to be metaphysically connected and behaving on one accord or in unison.

Critically, as a result of the physically separating maafa experience, many African Americans are not fully aware of their African self and are in need of the type of parenting guidance offered by scholars such as Robert L. Williams (2013). Yet, studies continue to find a link between African American cultural practices and the common practices of African people's in the Motherland (Akbar 2003; Nobles 1978). These shared behaviours support the notion of a common metaphysical connectivity between African Americans and Africans. Perhaps the strongest evidence of sameness is found when examining the way in which each group has exhibited supernatural strength in the face of past and present adversities. The ability to move forward after traumatic events is ill-defined by the western informed concept of resilience (American Psychological Association Task Force on Resilience and Strength in African American Children and Adolescents 2008). The remarkable ability of both Africans and African Americans to overcome extraordinary threats to 
their physical, psychological, cognitive functioning can only be defined through comprehension of their African essence or ngolo. The ngolo is the source of the strength that continues to equip African cultural affinity groups with the ability to overcome a host of traumatic events that include, but are not limited to, colonialism, apartheid, the transatlantic slave trade, national and civil wars, disease, famine, psychic terrorism (Nobles 2014), lynching, and barbaric scientific experimentation.

Africans, as aware Spirit Beings, must not be distracted by what is presented by westerners as a 'helping hand' to assist with restoration following man-made and natural disasters. The United Nation's UNCRC offers an example of this arrogant pseudo-benevolence (Masowa et al. 2013). African Americans, as African diasporic people, must not ignore their Spirit defined and Spirit driven selves that is naturally within them; this Spirit is evidence of their African essence and must be recognised as such. The children of both groups are being subjected to multiple adversities that negatively impact their functioning. Protection and healing from these experiences can be found by tapping into their African energy source and their African connectivity. The African child must be reminded of their African Spirit nature and the African American child must become conscious of the African Spirit within them.

In the USA, the trauma-informed or TI approach is being promoted as best practice for improving the mental wellness of trauma exposed individuals. African Americans, more than any other USA group, collectively have collectively been disproportionately subjected to historical and current racially-informed, systemic and individual trauma. As such, they are the primary targets for TI intervention models (Complex Trauma Treatment Network of the National Child Traumatic Stress Network 2016); the psychological impact of COVID-19 predictably will result in greater targeting of African Americans as a high profit market of mental health services. The TI western conceived approach, similar to most Eurocentric theories and concepts, do not acknowledge/recognise the African nature of African Americans and therefore offers little to no benefits to their targeted Black clients. To effect real care, an Afrikan-Informed or AKI (2019) approach is required and can best occur between African peoples.

Becoming Afrikan-Informed (Nunley 2019) is simply assisting African American children in knowing that they are African in nature, while being American in nurture (Nobles 1984). Nunley conceived the 'Five B's of Blackness' (2019) as a strategy for parents and caregivers of young African 


\section{Patricia Nunley}

American children to assist them in awakening their African identity. In gaining African self-knowledge they will learn that they are not only Spirit Beings, but also have an extended-self-identity. Their tri-fold identity extends to all beings in the past, present, and future in both the visible and invisible worlds and is made possible by the fact that they are Spirit Beings. Being informed about one's Africanness will allow them to know that, as Africans, they are never alone and that they are developing their Spirit. These children must learn that as Spirit Beings they are standing on a higher ground that has been previously prepared for them. As Spirit Beings (Akbar 1985), their role is to discover their individual service to all Beings (Nsamenang 2006); and to know this is the sacred call for all African people that positions them as leaders and not followers. Cakata (2019) reminds us that as Africans we must position ourselves not as purveyors of social justice but as living examples of the human justice that was once found in the village where umntu uhlala engumntu (a human being remains a human being) was once practiced. As living adult Spirit Beings, we must teach our children that humanity and harmfulness cannot, and should not, be allowed to co-exist (Cakata 2019).

\section{Conclusion: Our Sacred Duty}

Unconstrained western research has functioned to make the African child double invisible (Jonsson 2009; Nsamenang 2007) and the African American child 'double visible' (Jackson \& Moore 2008; Kunjufu 1992). As the living adult Spirit Beings, African and African American child development professionals, scholars, and caregivers, must re-visit their scared call as leaders and no longer allow humanity's youngest children, i.e. Europeans, to function as the wise elders to whom we look for instructions on how to raise our children. Javangwe and Chirisa (2013) are among the African scholars who recognise the wealth of knowledge that exists in the Motherland and have engaged in the process of documenting this reality. The western obsession with materialism (Kambon 1992), has resulted in western scholars' extensive documentation on their long history of murder, abuse, and neglect committed by parents and other adults toward their children (Crosson-Tower 2010; Piers 1978; Wolfe 1991). Notably, during medieval times, infants were viewed as talented pets, who were interesting because they could speak (Aries 1962). This slowly maturing European/ Western people group's comprehension of human childhood as a protected life stage is recent (Walker, Bonner \& 
Kaufman 1988; Wolock \& Horowitz 1984) and therefore Africans and African Americans must not be fooled into believing they possess special knowledge. A child cannot know what an elder knows, because he is still learning about how to be. As Spirit people, and the human life elders, we possess a rich body of knowledge gained from the experience of living and rearing the original child (Masowa et al. 2013).

Our primary focus must not be controlling western scholarship's illinformed arrogance about our Black children. As living adult Spirit Beings our critical task must be ensuring that our children are aware that they are African Spirit Beings who are growing and developing in a human body (Akbar 1985; Hillilard 1998). It is our sacred duty to make our children aware of the generative power that exists in their individual ngolo and that they are connected to all African people past, present, and future. This awareness is the key to improved functioning of all Black people and especially the young children who based on their young chronological age are in the first stage of 'becoming' fully functioning Spirit Beings (Fi-Kiau \& Lukondo-Wamba, 1998). For the young African American child who is growing and developing geographically away from their African Motherland, African self-knowledge and discovery of their ngolo, self-healing energy (Fu-Kiau 1991) is foundational for a successful journey toward wholeness and wellness that all children, regardless of their ethnicity, rightfully deserve.

\section{References}

Abney, V. \& R.R. Priest 1995. African American and Sexual Child Abuse. In L.A. Fontes (ed.): Sexual Abuse in Nine North American Cultures. Thousand Oaks, CA: Sage.

American Psychological Association, Task Force on Resilience and Strength in Black Children and Adolescents 2008. Resilience in African American Children and Adolescents: A Vision for Optimal Development. Washington, DC: Author. Available at:

http://www.apa.org/pi/cyf/resilience.html

Akbar, N. 2003. Akbar Papers in African Psychology. Tallahassee, FL: Mind Productions.

Akbar, N. 1985. The Community of Self Revised. Tallahassee, FL: Mind Productions. 
Allen, R.L. \& R.P. Bagozzi 2001. Consequences of the Black Sense of Self. Journal of Black Psychology 27: 3 - 28.

https://doi.org/10.1177/0095798401027001001

Alexander, M. 2010. The New Jim Crow. New York, NY: New Press.

Aries, P. 1962. Centuries of Childhood: A Social History of Family Life. Baldrick, R. (trans.). New York, NY: Vintage.

Barnett, O.W., C.L. Miller-Perrin \& R.D. Perrin 2011. Family Violence across the Lifespan. $3^{\text {rd }}$ Edition. Thousand Oaks, CA: Sage.

Bey, R. 2004. 'AIDS Orphans' and the Future: A Second Look at our Predictions. AIDS Bulletin (MRC) 13:2.

Bonvillian, C. 2020, 4 August. Police Force 4 Black Children onto Ground at Gunpoint Over Stolen Care Mix-up. Available at:

https://www.kiro7.com/news/trending/video-shows-police-force-4-

black-children-onto-ground-gunpoint-stolen-car-mix-

up/OYBP33R7R5BUZJYD5UMP34ENSU/

Brown, R.J. 2018. Trump Slurs Haiti, African Nations as 'Shithole Countries'.

Available at: https://nypost.com/2018/01/11/trump-reportedly-smearshaiti-africa-as-s-tholes/

Cakata, Z. 2019. Social Justice of My Neighborhood: Drawing from Home (Ubulungisa Ngokolwazi Lwabamelwane Bam: Ingqiqo Yasekhaya). Ubuntu Consultant Connecting Healers Newsletter 1,7: 15 - 16.

Complex Trauma Treatment Network of the National Child Traumatic Stress Network 2016. Complex Trauma: In Urban African-American Children, Youth, and Families. Los Angeles, CA, \& Durham, NC: National Center for Child Traumatic Stress. Available at:

https://www.nctsn.org/resources/complex-trauma-urban-africanamerican-children-youth-and-families

Conte, J. \& D. Shor 1982. Social Work and Sexual Abuse. Journal of Social Work and Human Sexuality 1, 1-2: 1 - 19.

https://doi.org/10.1300/J291v01n01 01

Cross, W. E., Jr. 1995. The Psychology of Nigrescence: Revising the Cross Model. In Ponterotto, J.G., J.M. Casas, L.A. Suzuki \& C.M. Alexander (eds.): Handbook of Multicultural Counseling. London \& New Delh: Sage Publications, Inc.

Crosson-Tower, C. 2010. Understanding Child Abuse and Neglect. $8^{\text {th }}$ Edition. Boston, MA: Allyn \& Bacon.

Dane, B.O. 1994. Death and Bereavement. In Dane, B.O. \& C. Levine (eds.): 
AIDS and the New Orphans: Coping with Death. Westport, CT: Auburn House.

Darwin, C. 1977. Biographical Sketch of an Infant. Mind os-2,7, July,11877:

285 - 294. https://doi.org/10.1093/mind/os-2.7.285

Fu-Kiau, K.K.B. 1969. La Comogonie Kongo. Kin, Zaire: ONRD.

Fu-Kiau, K.K.B. 1991. Self-Healing Power and Therapy: Old Teachings from

Africa. Imprint Editions, Baltimore, MD: Black Classical Press.

Fu-Kiau, K.K.B. \& A.M. Lukondo 1998. Kindezi: The Kongo Art of Babysitting. Baltimore, MD: Black Classic Press.

Gaines, K. 2016. August 2. Photography is not a Crime. Available at:

https://www.youtube.com/watch?v=IPG7HYGQlaA

Hale-Benson, J. 1986. Black Children: Their Roots, Culture, and Learning Styles. Revised Edition. Baltimore, MD: Johns Hopkins University Press. Hill, R.B. 2003. The Strengths of Black Families. Lanham, MD: University Press of America.

Hilliard, A.G. 1998. SBA: The Reawakening of the African Mind. Foreword by

Wade W. Nobles. Gainesville, FL: Makare Publishing Company.

Iruka, I.U., S.M. Curention, T.R. Durden \& K. Escayg 2020. Don't Look Away: Embracing Anti-bias Classrooms. Lewisville, N.C.: Gryphon House.

Jackson, J.F.L. \& J. Moore 2008. Introduction: The African American Male Crisis in Education: A Popular Media Infatuation or Needed Public Policy Response. American Behavioral Scientist 51,7: 847 - 853.

https://doi.org/10.1177/0002764207311992

Javangwe, G. \& I. Chirisa 2013. Navigating the Contours of African Childhood Experiences: Multidisciplinary Perspectives. Palo Alto, CA: Academica Press.

Jonsson, U. 2009. The Double Invisibility: The Knowledge Deficit and Children in Africa Global Conference on Research and Child Rights. Addis Abada.

Kapsalis, T. 1997. Public Privates: Performing Gynecology from Both Ends of the Speculum. Durham: NC. Duke University Press.

Kambon, K.K.K. 2012. African/ Black Psychology in the American Context: An African-Centered Approach. $2^{\text {nd }}$ Edition. Tallahassee, FL: Nubian Nation Publications

Kunjufu, J. 1995. Countering the Conspiracy to Destroy Black Boys Series. Chicago, IL: African American Images. 
Latif, N. \& S.A. Latif 1994. Slavery: The African American Psychic Trauma.

Chicago, IL: Latif Communication Group, Inc.

Laurencin, C.T. \& J.M. Walker 2020. A Pandemic on a Pandemic: Racism and

COVID-19 in Blacks. Cell Systems 11,1: 9 - 10.

https://doi.org/10.1016/j.cels.2020.07.002

Mapping Police Violence. https://mappingpoliceviolence.org/

Masowa, A., T.L. Gopo \& Z. Mamvura 2013. Children's Rights not a New

Phenomenon in Africa: A Comparative Analysis of Children's Rights as

Depicted in Selected Shona/ Ndebele Folktales and The Children's Rights in the United Nation Conventions. In Javangwe, J. \& I. Chirisa (eds.): Navigating the Contours of African Childhood Experiences: Multidisciplinary Perspectives. Palo Alto, CA: Academica Press.

Mbiti, J.S. 1970. African Religions and Philosophy. New York, NY: Anchor Books.

McAdoo, H.B. 2006. Black Families. Thousand Oaks, CA: Sage.

McLaughlin, E.C. \& A. Vera 2020, 24 August. Wisconsin Police Shoot a Black Man as his Children Watch from a Vehicle, Attorney Says. Available at: https://www.cnn.com/2020/08/24/us/kenosha-policeshooting-jacob-blake/index.html

National Scientific Council on the Developing Child 2015. Supportive Relationships and Active Skill-Building Strengthen the Foundations of

Resilience. Working Paper. Available at:

https://developingchild.harvard.edu/science/key-concepts/resilience/

Nobles, V.L. 2015. Ebonics: The Retention of African Tongues. Shujaa, M. \&

K. Shujaa (eds.): Encyclopedia of African Cultural Heritage. Thousand Oaks, CA: Sage.

https://doi.org/10.4135/9781483346373.n126

Nobles, W.W. 1978. The Black Family and its Children: The Survival of Humanness. Black Books Bulletin 6,2: 7 -16

Nobles, W.W. 1984. Standing in the River Transformed and Transforming: The (Re)-ascension of Psychology. In Nobles, W.W. (ed.): African Psychology. Oakland, CA: A Black Family Institute Publication.

Nobles, W.W. 2001. To be African. Psych Discourse August,32, \#8.

Nobles, W.W. 2014. Cultural Resistance to Psychic Terrorism. In Shujaa, M. \& K. Shujaa (eds.): Encyclopedia of African Cultural Heritage.

Thousand Oaks, CA: Sage.

Nobles, W.W. 2017. Personal Communication. 
Nsamenang, A.B. 2006. Human Ontogenesis: An Indigenous African View on Development and Intelligence. International Journal of Psychology 41,4: 293 - 297. https://doi.org/10.1080/00207590544000077

Nsamenang, A.B. 2007. A Critical Peek at Early Childhood Care and Education in Africa. Child Health and Education 1,1: 14 - 26.

Nunley, P.L. 2019. Trublin' Da' Wada (Troubling the Water): The AfrikanInformed Approach to Addressing the Psychic Terrorism (Trauma) Experienced by African Americans. Unpublished Paper.

Nunley, P. L. 2019. 'Black to School' Affirmation Gives Black Students a Tool for Coping in Classroom. Available at:

https://www.postnewsgroup.com/black-to-school-affirmation-givesblack-students-a-tool-for-coping-in-classroom/

Olafson, E., D.L. Corwin \& R.C.M Summit 1993. Modern History of Child Sexual Abuse: Cycles of Discovery and Suppression. Child Abuse and Neglect 17:7 - 24.

https://doi.org/10.1016/0145-2134(93)90004-O

Piaget, J. 1963. The Origins of Intelligence in Children. New York: W.W. Norton \& Company, Inc.

Piers, M.W. 1978. Infanticide: Past and Present. New York, NY: Norton.

Roberts, D. 1997. Killing the Black Body: Race, Reproduction and the Meaning of Liberty. New York, NY: Vintage Books.

Rush, F. 1991. The Best Kept Secret: Sexual Abuse of Children. New York: Tab Books.

Schladebeck, J. 2017. Daughter of Philando Castile's Girlfriend Begs Mom to Keep Calm after Fatal Traffic Stop: 'I don't want you to get shooted'. New York Daily News. Available at:

https://www.nydailynews.com/news/world/authorities-release-newvideo-philando-castile-shooting-article-1.3266415

Skinner, B.F. 1945. Baby in a Box: The Mechanical Baby-Tender. The Ladies Home Journal 62: 30 - 31, 135 - 136, 138.

Solheim, K. 2003. 'War Don Don': A Study of the Reconciliation Process in Post-War Sierra Leone, with a Focus on the Young Ex-Combatants. Oslo: Oslo University College.

Spencer, M.B. 1995. Old Issues and New Theorizing about African American Youth: A Phenomenological Variant of Ecological System Theory. In Taylor, R.L. (ed.): Black Youth: Perspectives on their Status in the United States. Westport, CT: Praeger. 
Staples, R. 1977. The Black American Family. In Mindle, C.H. \& R.W. Habenstein (eds.): Ethnic Families in America: Patterns and Variation. New York: Elsevier

Toldson, I.A. 2019. NO BS (Bad Stats) Black People Need People Who Believe in Black People Enough Not to Believe Every Bad Thing they Hear about BLACK PEOPLE. Leiden, The Netherlands; Koninklijke Brill NV. https://doi.org/10.1163/9789004397040

Twum-Danso, A. 2003. Africa's Young Soldiers. The Co-option of Childhood Monograph 82 1,1-2: 201 - 211.

https://doi.org/10.1186/1475-2883-2-S1-S3

Washington, H.A. 2006. Medical Apartheid: The Dark History of Medical Experimentation on Black Americans from Colonial Times to the Present. New York: Random House

Wen, L. \& K. Goodwin 2016. Violence is a Public Health Issue. Journal of Public Health Management and Practice 22, 6: 503 - 505.

https://doi.org/10.1097/PHH.0000000000000501

Wild, L. 2001. The Psychosocial Adjustment of Children Orphaned by AIDS.

Southern African Journal of Child and Adolescent Mental Health 13,1: 3

- 22. https://doi.org/10.1080/16826108.2001.9632388

Williams, R.L. 2013. Raising Black Kids to Be OK. Indianapolis, IN; Dog Ear Publishing.

Wilson, A.N. 1992. Awakening the Natural Genius of Black Children. New York, NY: Afrikan World InfoSystems.

Wolfe, D.A. 1991. Preventing Physical and Emotional Abuse of Children. New York, NY: Guilford.

Wolock, T. \& B. Horowitz 1984. Child Maltreatment as a Social Problem. The Neglect of Neglect. American Journal of Orthopsychiatry 54: 530 - 542. https://doi.org/10.1111/j.1939-0025.1984.tb01524.x

Patricia Nunley Assistant Professor Hilliard-Sizemore Fellow Child Development and Family Studies City College of San Francisco pnunley@ccsf.edu 